\title{
A realist evaluation of the formation of groups of people with disabilities in North India
}

\section{Rebekah Young ${ }^{a}$, Matthew Reeve, ${ }^{b}$ Alex Devine, ${ }^{c}$ Lawrence Singh, ${ }^{d}$ Nathan Grills ${ }^{e}$}

${ }^{a}$ MS-IV, The Nossal Institute for Global Health, The University of Melbourne, Australia

${ }^{\mathrm{b}} \mathrm{PhD}$, Senior Project Officer, Nossal Institute for Global Health

${ }^{c}$ Senior Research Officer at the Nossal Institute for Global Health

${ }^{d}$ Project Coordinator, HOPE Project, Agnes Kunze Society, Dehradun, India

e MBBS, MPH, DPhil, Nossal Institute of Global Health, University of Melbourne, Australia

\section{Abstract}

Background: Disabled Peoples' Organisations (DPOs) are organisations established by and for people with disabilities. Formation of Disabled Peoples' Groups (DPGs) and DPOs in low- and middle-income countries is currently one method for implementing disability-inclusive development strategies. While there is evidence that such groups can achieve beneficial outcomes for people with disabilities, they seem to form and function differently in different settings and little is understood about why this is the case. This study aimed to explore how and why different factors affect the development and operation of DPGs by investigating the contextual factors and mechanisms that enable and hinder the formation and functioning of DPGs in North India.

Methods: This study adopted a realist approach to evaluation. Preliminary contextmechanism-outcome configurations were developed, tested empirically, and refined by undertaking five case studies in the state of Uttarakhand, India.

Results: Results from this study were grouped under the broad, emergent themes of factors related to: 1) external supports; 2) community and physical environment; and 3) group composition. It was found that external entities could support the development of DPGs by advocating for the rights of people with disabilities, and providing information, knowledge, and funding to groups. Support from local village leadership was central to facilitating group formation and functioning, but the benefit of this support was amplified when DPGs formed strong networks with other similar groups. DPGs displayed a capacity for stimulating positive societal changes in regard to disability through influencing societal understandings of disability, and improving inclusion and participation of people with disabilities.

Conclusions: While the results of this study were specific to the context in which it was undertaken, many findings were consistent with those in the literature, suggesting that there may be common principles that can be applied to other contexts. By providing insight into the contextual factors that affected DPG formation and function, the findings of this study may assist those involved in DPG formation to adapt models and methods to better suit specific contexts.

Nov 2016. Christian Journal for Global Health, 3(2): 72-90. 


\section{Background}

All people with disabilities include those who have long-term physical, psycho-social, intellectual, or sensory impairments that in interaction with various barriers, hinder their full participation in society on an equal basis with others. ${ }^{1}$ Disability affects over one billion people worldwide, and the World Health Organization (WHO) estimates that over $80 \%$ of people with disabilities live in lowand middle-income countries (LMIC) where access to health and social services is restricted. ${ }^{2,3}$ In India, there is a growing realisation of the prevalence of disability, and an increasing understanding of the need to support the rights of people with disabilities. ${ }^{4,5}$

Disabled Peoples' Organisations (DPOs) are organisations established by and for people with disabilities. ${ }^{6}$ DPOs grew out of the Disability Rights Movement of the 1970s and have a variety of functions including advocacy, promotion of mutual support, solidarity, and self-representation for people with disabilities. ${ }^{2,6-8}$ Groups like these already operate in many different parts of the world, and their formation in LMICs is a key part of disability-inclusive development strategies. In some contexts, organisations involved in disabilityinclusive development work in partnership with people with disabilities to bring together groups of people with disabilities (hereafter referred to as DPGs) that may go on to become DPOs. A review of the literature revealed that DPGs in LMICs could promote the wellbeing, participation, and rights of people with disabilities, although little is understood about how contextual factors (particularly the involvement of external supports) influence group formation and function. ${ }^{9}$ This paper investigates the contextual factors and mechanisms that enabled and hindered the formation and function of DPGs in a North Indian context.

\section{Methods}

\section{Realist impact evaluation}

Realist evaluation explores theories of what works where, how, and for whom. ${ }^{10-12}$ Realist theory understands the world as an open system in which multiple (contextual) factors work together to influence what happens (outcomes) and how various factors work (mechanisms) to achieve these outcomes. Realist impact evaluation addresses questions of causation (how a program or intervention causes change) and attribution (the extent to which observed changes can be attributed to the program or intervention or other factors) using a realist framework. Undertaking a realist impact evaluation involves first developing a "program theory" which can then be tested and refined through data collection and analysis. Under a realist approach, program theories are comprised of several hypotheses that aim to suggest for whom and in what contexts the intervention is likely to work, the mechanisms by which the intervention is likely to have an effect, and the possible outcomes that will be observed if the intervention works as expected. The strength of realist methodology is its capacity to explore not just whether or not an intervention works in a particular context, but also how and why it works in that context. It was for these reasons that a realist methodology was selected for use in this study.

In applying the realist approach to this evaluation, the authors developed a testable program theory using context-mechanism-outcome configurations (CMOCs) that attempted to capture the complexity of how an externally-driven intervention promoted the formation of DPGs in and among particular populations and contexts in Northern India to bring about particular outcomes. These CMOCs were informed by a review of the literature, a synthesis of existing program documents (provided by the field managers of the DPGs included in this study), and a preliminary field visit in $2015 .^{9}$ Initial CMOCs for this study were grouped under three broad themes: involvement of an external entity; the role of key contributors; and group composition (Appendix 1). 


\section{Case study design}

The initial program theory was tested empirically, and refined by conducting and analysing five case studies of externally-supported DPGs in Uttarakhand, North India. Three case study sites were located in the plains regions of Dehradun District and two in the mountain regions of Tehri Garhwal District (see Table 1 and Appendix 2 for detail).

Table 1: Case study demographic details

\begin{tabular}{|c|c|c|c|c|c|c|c|c|c|c|}
\hline $\begin{array}{l}\text { Site and } \\
\text { number } \\
\text { of DPGs } \\
\text { at site }\end{array}$ & $\begin{array}{l}\text { Month } \\
\text { and year } \\
\text { of first } \\
\text { group } \\
\text { meeting }\end{array}$ & $\begin{array}{l}\text { Number } \\
\text { of DPG } \\
\text { members } \\
\text { at site } \\
(\mathrm{M}, \mathrm{F})\end{array}$ & $\begin{array}{l}\text { Age } \\
\text { range }\end{array}$ & Caste* & $\begin{array}{l}\text { Marital } \\
\text { status } \\
* *\end{array}$ & $\begin{array}{l}\text { Education } \\
\text { level of } \\
\text { members }\end{array}$ & Employment & Location & $\begin{array}{l}\text { Grp } \\
\text { fin- } \\
\text { ance } \\
* *\end{array}$ & $\begin{array}{l}\text { Net- } \\
\text { work } \\
\text { with } \\
\text { other } \\
\text { DPO }\end{array}$ \\
\hline $\begin{array}{l}\text { Chamba } \\
2\end{array}$ & $\begin{array}{l}\text { August } \\
2015\end{array}$ & $\begin{array}{c}61 \\
(39 \mathrm{M}, 22 \mathrm{~F})\end{array}$ & $\begin{array}{l}32-69 \\
\text { years }\end{array}$ & $\begin{array}{l}\text { SC: } 2 \\
\text { G: } 59\end{array}$ & $\begin{array}{l}\text { M: } 34 \\
\text { U: } 17\end{array}$ & $\begin{array}{l}\text { Illiterate: } 8 \\
\text { Primary } \\
\text { school: } 6 \\
\text { High } \\
\text { school: } 21 \\
\text { Universty: } 3 \\
\text { Not rep'ted: } 5\end{array}$ & $\begin{array}{l}\text { Unemployed: } 8 \\
\text { Farmer: } 24 \\
\text { Labourer: } 5 \\
\text { Shopkeeper: } 1 \\
\text { Hotel: } 2 \\
\text { Anganwadi } \\
\text { worker: } 1 \\
\text { Not reported: } 3\end{array}$ & $\begin{array}{l}\text { Panchayat } \\
\text { house }\end{array}$ & B & No \\
\hline $\begin{array}{l}\text { Thatyur } \\
3\end{array}$ & $\begin{array}{l}\text { January } \\
2015\end{array}$ & $\begin{array}{l}26 \text { (gender } \\
\text { breakdown } \\
\text { not } \\
\text { available } \\
\text { for all } \\
\text { groups) } \\
\text { Mixture of } \\
\text { people } \\
\text { with and } \\
\text { without } \\
\text { disabilities }\end{array}$ & $\begin{array}{l}18-66 \\
\text { years }\end{array}$ & $\begin{array}{l}\text { SC: } 11 \\
\text { G: } 8 \\
\text { OBC: } 7\end{array}$ & $\begin{array}{l}\text { M: } 23 \\
\text { U: } 3\end{array}$ & $\begin{array}{l}\text { Illiterate: } 0 \\
\text { Primary } \\
\text { school: } 1 \\
\text { High } \\
\text { school: } 8 \\
\text { University: } 0 \\
\text { Not rep'ted: } 17\end{array}$ & $\begin{array}{l}\text { Unemployed: } 2 \\
\text { Carpenter: } 2 \\
\text { Farmer: } 22\end{array}$ & $\begin{array}{l}\text { Panchayat } \\
\text { house }\end{array}$ & $\mathrm{E}$ & No \\
\hline $\begin{array}{l}\text { Raipur } \\
3\end{array}$ & $\begin{array}{l}\text { May } \\
2015\end{array}$ & $\begin{array}{l}56 \text { (gender } \\
\text { breakdown } \\
\text { not available } \\
\text { for all } \\
\text { groups) } \\
\text { Mixture of } \\
\text { people with } \\
\text { and without } \\
\text { disabilities }\end{array}$ & $\begin{array}{l}17-70 \\
\text { years }\end{array}$ & $\begin{array}{l}\text { Not } \\
\text { reported }\end{array}$ & $\begin{array}{l}\text { M: } 40 \\
\text { U: } 9 \\
\text { Not } \\
\text { reported: } \\
6\end{array}$ & $\begin{array}{l}\text { Illiterate: } 17 \\
\text { Primary school } \\
13 \\
\text { High school: } 14 \\
\text { University: } 4 \\
\text { Not rep'ted: } 7\end{array}$ & $\begin{array}{l}\text { Unempl'ed: } 20 \\
\text { Housewife: } 5 \\
\text { Labourer: } 8 \\
\text { ASHA: } 1 \\
\text { Driver: } 1 \\
\text { Tailor: } 1 \\
\text { Shop keeper: } 4 \\
\text { Gardener: } 1 \\
\text { Contracter: } 1 \\
\text { Guard: } 2 \\
\text { Factory work: } 1 \\
\text { Mechanic: } 1 \\
\text { Unspecified: } 10\end{array}$ & $\begin{array}{l}\text { Panchayat } \\
\text { house }\end{array}$ & $\mathrm{E}$ & No \\
\hline
\end{tabular}




\begin{tabular}{|c|c|c|c|c|c|c|c|c|c|}
\hline $\begin{array}{l}\text { Vikars } \\
\text { Nagar } \\
1\end{array}$ & $\begin{array}{l}\text { May } \\
2015\end{array}$ & $\begin{array}{l}18 \text { (gender } \\
\text { breakdown } \\
\text { not } \\
\text { available) } \\
\text { Mixture of } \\
\text { people with } \\
\text { and without } \\
\text { disabilities }\end{array}$ & $\begin{array}{l}20-60 \\
\text { years }\end{array}$ & $\begin{array}{l}\text { SC: } 4 \\
\text { OBC: } 14\end{array}$ & $\begin{array}{l}\mathrm{M}: 9 \\
\mathrm{U}: 8\end{array}$ & $\begin{array}{l}\text { Illiterate: } 0 \\
\text { Primary school } \\
4 \\
\text { High school: } 6 \\
\text { University: } 1 \\
\text { Not reported: } 6\end{array}$ & $\begin{array}{l}\text { Painter: } 3 \\
\text { Shop keeper: } 3 \\
\text { Tailor: } 1 \\
\text { Mason: } 1 \\
\text { Labourer: } 2 \\
\text { Not reported: } 8\end{array}$ & $\begin{array}{l}\text { Panchayat B } \\
\text { house }\end{array}$ & No \\
\hline $\begin{array}{l}\text { Sahaspur } \\
3\end{array}$ & $\begin{array}{l}\text { May } \\
2015\end{array}$ & $\begin{array}{l}69 \text { (gender } \\
\text { breakdown } \\
\text { not available } \\
\text { for all } \\
\text { groups) } \\
\text { All people } \\
\text { with } \\
\text { disabilities }\end{array}$ & $\begin{array}{l}18-76 \\
\text { years }\end{array}$ & $\begin{array}{l}\text { SC: } 8 \\
\text { ST: } 20 \\
\text { G: } 20 \\
\text { Not } \\
\text { reported: } \\
21\end{array}$ & $\begin{array}{l}\text { M: } 44 \\
\text { U: } 33 \\
\text { Not } \\
\text { reported: } \\
2\end{array}$ & $\begin{array}{l}\text { Illiterate: } 0 \\
\text { Primary school: } \\
19 \\
\text { High school: } 14 \\
\text { University: } 3 \\
\text { Not reported: } \\
31\end{array}$ & $\begin{array}{l}\text { Shop owner: } 4 \\
\text { House wife/at } \\
\text { home: } 45 \\
\text { Tailor: } 5 \\
\text { Labourer: } 9 \\
\text { Teacher: } 2 \\
\text { Student: } 1 \\
\text { Anganwadi } \\
\text { worker: } 1 \\
\text { Barber: } 1\end{array}$ & $\begin{array}{l}\text { Boarding } \text { B } \\
\text { house } \\
\text { facility }\end{array}$ & No \\
\hline
\end{tabular}

The case study sites were purposively selected according to the location of several NonGovernmental Organisations (NGOs) that were involved in implementing a disability-inclusive intervention as part of an on-going study of disability-inclusion in Uttarakhand. ${ }^{5}$ Since 2015, NGOs at each site have worked collaboratively with people with disabilities to form DPGs, and promote their independence in the hope that groups may sustain their activities and go on to form DPOs. Prior to the commencement of this study, the included NGOs had been working across a range of different areas in their local communities such as in mental health, education, and community health care. The NGOs were not primarily staffed by people with disabilities.

The researcher (RY) visited each site between February and March 2016, and undertook a triangulated approach including: a focus group discussion (FGD) with DPG members (primarily people with disabilities and in some cases parents and/or care givers); semi-structured interviews (SSI) with key informants (usually the village leader and/or a community health worker); and an
SSI with the Field Manager (FM) for each DPG (a representative of the NGO that was providing support to the DPG) (see Appendix 3 for interview guides). The researcher also kept a field diary of observations made at each site, and compiled and reviewed key documents for each DPG.

Participants for this study were selected from the DPGs and networks of partner organisations with assistance from the FMs at each site (Table 2). Participants were purposively selected for their level of involvement in the DPG with preference being given to individuals who had had regular involvement (i.e., regular attendance) with the groups.

All data were transcribed and translated into English, then grouped according to major themes. CMOCs were refined between site visits as data emerged, and the refined CMOCs were then tested at successive sites.

\section{Ethics}

Research was undertaken with the approval of University of Melbourne Human Research Ethics Committee (HREC). 
Table 2: Demographics of study participants

\begin{tabular}{|c|c|c|c|}
\hline Type of interview & $\begin{array}{l}\text { Total number of } \\
\text { participants }\end{array}$ & Male, Female & $\begin{array}{l}\text { Number of people with disabilities and type of } \\
\text { disability }\end{array}$ \\
\hline \multicolumn{4}{|l|}{ Tehri Garhwal District } \\
\hline SSI (NGO) & 3 & $3 \mathrm{M}, \mathrm{OF}$ & 0 \\
\hline SSI (Key informant) & $\begin{array}{l}3 \\
\text { - Village leader: } 1 \\
\text { - Health worker: } 2\end{array}$ & $1 \mathrm{M}, 2 \mathrm{~F}$ & 0 \\
\hline FGD & 15 & $9 \mathrm{M}, 6 \mathrm{~F}$ & $\begin{array}{l}12 \text { Motor impairment: } 7 \\
\text { - Sensory impairment: } 3 \\
\text { - Intellectual impairment: } 0 \\
\text { - Mixed impairment: } 0 \\
\text { - Unspecified: } 2 \\
\end{array}$ \\
\hline \multicolumn{4}{|l|}{ Dehradun District } \\
\hline SSI (NGO) & 5 & $2 \mathrm{M}, 3 \mathrm{~F}$ & $\begin{array}{l}1 \\
\text { Motor impairment: } 1\end{array}$ \\
\hline SSI (key informant) & $\begin{array}{l}3 \\
\text { - Village leader: } 3 \\
\text { - Health worker: } 0\end{array}$ & $3 \mathrm{M}, \mathrm{OF}$ & 0 \\
\hline FGD & 37 & $21 \mathrm{M}, 16 \mathrm{~F}$ & $\begin{array}{l}28 \\
\text { - Motor impairment: } 18 \\
\text { - Sensory impairment: } 4 \\
\text { - Intellectual impairment: } 1 \\
\text { - Mixed impairment: } 1 \\
\text { - Unspecified: } 4\end{array}$ \\
\hline
\end{tabular}

\section{Results}

The results from this study were grouped under the broad themes of factors related to: 1) external supports; 2) community and physical environment; and 3) group composition (Table 3). In summary, it was found that external entities could support the development of DPGs by advocating for the rights of people with disabilities and providing information, knowledge, and funding to groups. Support from local village leadership was required for group formation and functioning, and networks between DPGs and other similar groups were also beneficial. In this study, DPGs displayed a capacity for stimulating positive societal changes in regard to disability through influencing societal understandings of disability, and improving inclusion and participation of people with disabilities.

Table 3: Context-mechanism-outcome configurations - CMOCs

\begin{tabular}{lll}
\hline Context & & Mechanism \\
\hline External supports & & Outcome \\
\hline $\begin{array}{l}\text { Association of DPG } \\
\text { with NGO in early } \\
\text { phase of group } \\
\text { formation }\end{array}$ & $\begin{array}{l}\text { Idea of DPG formation } \\
\text { introduced by NGO who were } \\
\text { responsible for stimulating } \\
\text { group formation }\end{array}$ & $\begin{array}{l}\text { NGO largely responsible for group functioning early on with } \\
\text { limited ownership of groups by people with disabilities in the } \\
\text { early phases }\end{array}$ \\
& $\begin{array}{l}\text { Modelling of good governance } \\
\text { strategies and organisational } \\
\text { structures, and acting as an } \\
\text { initial source of information } \\
\text { and knowledge for groups }\end{array}$ & $\begin{array}{l}\text { Establishment of group register and record-keeping } \\
\text { Contribution of members to group funds } \\
\text { Registration as an official DPO }\end{array}$ \\
\hline
\end{tabular}

Nov 2016. Christian Journal for Global Health, 3(2): 72-90. 
Religious background of staff of external entity (Christian), and belief that people with disabilities are made in the image of God and have equal worth with all other human beings

Presence of a group champion
Engagement with people with disabilities as fellow human beings and abandonment of moral or charity-model of engagement

Investment in disabilityinclusive strategies to promote participation of people with disabilities

Awareness raising and education provided to the community about the value and right of people with disabilities

Consistent contact with people with disabilities and their families

Trust development and relationship building Diffusion of innovation (DPG)

Involvement of NGOs in the Uttarakhand 'Cluster' network of community health organisations

Existing contacts and connections between staff and programs (and therefore connections between DPGs/DPOs via the FMs), value placed on relational collaboration by NGO staff, intentional efforts from NGO staff to facilitate networking relationships between DPGs/DPOs

\begin{tabular}{lll}
$\begin{array}{l}\text { Networks with other } \\
\text { DPGs (or similar } \\
\text { groups) }\end{array}$ & $\begin{array}{l}\text { Modelling of group function } \\
\text { Enthusiasm of DPG members } \\
\text { after seeing what has been } \\
\text { accomplished by other groups }\end{array}$ & $\begin{array}{l}\text { Earlier group formation } \\
\text { Nore rapid transfer of responsibility for group leadership from }\end{array}$ \\
$\begin{array}{l}\text { Knowledge and resource } \\
\text { sharing }\end{array}$ & Earlier access to government schemes and entitlements \\
& $\begin{array}{l}\text { Increased identity and } \\
\text { confidence through larger } \\
\text { group numbers }\end{array}$ & Increased participation of group members in broader society \\
\hline
\end{tabular}

Funding provision from external entity (NGO) in early phases of group formation
Ability of groups to focus on developing strong relationships in early phases of group formation

Protection against financial mis-dealings in early phases of group formation

Modelling of good financial practices

Enablement of DPGs to sustain organisational costs in early phase
Changes in societal beliefs about disabilities (curse to gift of nature), greater social inclusion for people with disabilities
Opportunities provided to DPGs to meet with other groups in their areas (where such groups existed) for the purpose of developing networking relationships
Retention of group members (due to the development of trusting relationships between members)
Election of a treasurer and transition to collecting contributions for group finances

Nov 2016. Christian Journal for Global Health, 3(2): 72-90. 


\section{Community and physical environment}

Support of local village leadership
Knowledge and information sharing

Provision of a group meeting place (neutral location, central)

Increased confidence in group members (perceived legitimacy of group if supported by local leadership)

Advocacy support given to group by Pradhan

Assistance from Pradhan in community education and awareness raising
Physical barriers in environment

Difficulty for people with disabilities to travel and to access locations and facilities

Increased involvement of NGO staff and family members required to link people with disabilities into groups

\section{Group composition}

People of diverse backgrounds (age, gender, religion, caste)
Disability seen as a unifying factor

Working together on a common task

Sharing and serving food and drink together as part of meetings

Increased self-confidence
Increased awareness of rights and of available government schemes and entitlements

Diversity in group composition

Regular group meetings

Increased visibility of people with disabilities in general society when travelling to and participating in group meetings and activities

Increased participation of people with disabilities in broader society

Changes in societal views toward disabilities

Tendency of groups to involve more 'well' people with disabilities (i.e. tendency of groups to exclude people with profound disabilities)

Decreased group ownership by people with disabilities

Low or inconsistent attendance at group meetings

\section{Relational cohesion among groups}

Representation of a broad range of views and different types of people within DPG

\section{Regular participation in meetings outside the home environment}

Opportunities to participate in leadership roles in the group
Increased opportunities to participate in broader society

Election of a treasurer and transition to collecting contributions for group finances

Note: This table is designed to give a simple overview of the CMOCs that have contributed to the findings presented in the results section of this paper. It necessarily simplifies complex thoughts and links between concepts and thus should be read in reference to the rest of this paper

\section{Summary: Factors related to external supports}

All DPGs in this study were initiated by NGOs as part of implementing a disability-inclusive intervention in Uttarakhand. ${ }^{5}$ Consequently, all groups received significant external support from
NGOs in the early phases of group formation, which was an important mechanism in the outcomes observed. 


\subsection{Information sharing and role-modelling by NGOs}

Initial input from NGOs in providing knowledge and information to DPGs seemed valuable to group members. "I feel that if we... are linked up with the NGOs, they can tell us or give us information and through them our work can be done easily" (DPG member). NGO staff assisted people with disabilities to develop their skills to lead effective groups by teaching and modelling organisational practices and governance structures, and slowly transitioning leadership responsibility to DPGs. One NGO staff member reported,

... From the start our team is always there for the monthly meetings... even conducting and facilitating the meetings... even how to fill out the register, the minutes of the meeting. Before we showed how to do it but now they [group members] are [doing it].

This theme of DPG members learning by example from NGOs emerged repeatedly throughout the study, with modelling appearing to be a key way of conveying information to DPGs.

Significant NGO involvement in the early phases of group formation created reliance on the NGO for group functioning. When asked if the group would continue to function if NGO staff no longer assisted it, one DPG member reported, "It won't work properly. The meetings wouldn't be on time... it won't be running." For another DPG, although the NGO was essential in forming the DPG, members agreed that if the NGO stopped assisting them now, "It will go well." Initial assistance from NGOs was seen to be beneficial to support people with disabilities to form DPGs, and promote their agency to eventually lead and govern such groups. More data is required, however, to investigate what happens to DPGs when external support is withdrawn.

\subsection{Religious beliefs of staff of external entity (NGO)}

The NGO staff repeatedly attributed their positive attitude toward people with disabilities to their Christian faith. Many NGO staff members echoed the sentiment of an FM who stated, “... I see persons with disability equally created in the image of God. God has given them different talents and gifts of which they can contribute." The belief of many NGO staff in an equal worth of all people seemed to encourage staff to engage with people with disabilities as equals rather than adopting a moral or charity-based model for engagement, historically a common approach to engaging with people with disabilities in the areas visited. ${ }^{13}$ There was evidence of societal views about disability changing as a result of DPG formation, education, and awareness-raising efforts by NGO staff and people with disabilities. Cultural understandings of disability in the areas visited were often couched in religious or spiritual terms, and changes in societal views were, in part, evidenced by modifications in the language used to describe disability. A village leader described these changes when he said, "First there was the thing of curse, but now there is nothing like this that prevails in society."

\subsection{The importance of leadership within the}

\section{NGO to strengthen disability inclusion}

The role of a leader within the NGO who assumed responsibility for strengthening disability inclusion efforts (hereafter referred to as the group champion) was central to DPG formation. The group champion was typically an NGO staff member who exercised leadership in raising awareness about DPGs, and developing trusting relationships with people with disabilities and their families to encourage them to form or join DPGs. One DPG member echoed the stories of many others when he described how his group was formed, saying, "The volunteer from the community hospital [NGO]... gave us awareness... then we made a group." The champions did not need to have a disability to effectively fulfil their role. 


\subsection{Networks with other groups enhance DPG functioning}

All participating NGOs that supported DPG formation in this study were part of a "cluster" network of community health organisations in Uttarakhand. The significance of this was that NGOs had links to one another and to other partner organisations before this study began. ${ }^{14}$ These preexisting relationships facilitated the arrangement of meetings and exposure visits between groups (where one DPG visited a DPO or similar group to observe and learn from their models and practices). Where collaborative relationships resulted from these meetings and exposure visits, DPGs seemed to benefit in several ways. Firstly, these networks fostered peer-led information and knowledge sharing. Secondly, they strengthened the identity and confidence of DPG members. An NGO staff member commented on his observations around the role of networking in group formation, saying:

[The relationship between the groups has been useful for]... resources and sharing information.

The other thing is... it gives them a bigger identity saying we are not just us, we also have other people out there like us.

These benefits of information, resource sharing, growing confidence, and strengthened identity seemed to accelerate the formation of DPGs. This was suggested by observations that groups with pre-existing networking relationships demonstrated greater knowledge and responsibility for self-governance than other groups. In mountain regions challenged by accessibility as well as a number of other factors, groups seemed slower to mature. Nevertheless, members of mountain-region DPGs affirmed, "Yes, we do want to meet [other groups]."

\subsection{Funding provision from external entities: important for initiation of groups}

All groups received little financial support from NGOs in the early stages of group formation. Data seemed to indicate that this early financial support allowed the formation of strong relationships in the DPGs by enabling groups to form trusting relationships before having to make personal contributions to group finances. Once groups transitioned to raising their own funds they began to exercise greater self-determination in allocating finances than before.

We use [group funds] to buy materials... or we keep it in the account or give it to the people who do not have money and who need it... We do not save much amount of money but whatever is collected is used for a good purpose (DPG member).

\section{Summary: Community and physical environment}

The formation and functioning of DPGs was influenced by the community environment and in turn exerted an influence on the community. Support from local village leadership facilitated DPG formation but did not appear to be sufficient to facilitate the formation of effective DPGs. Barriers in the physical environment significantly limited the ability of people with disabilities to participate in DPGs, and these barriers were slow to change in response to DPG formation.

\subsection{DPGs increased the confidence of people} with disabilities and stimulated changes in societal views on disability

Changes in societal beliefs about disabilities seemed to begin with changes in self-identification of people with disabilities. Becoming a member of a DPG reportedly helped people with disabilities develop confidence in their identity as part of a group, and seemed to increase their confidence to participate in society.

First, I used to be only at home and didn't meet anybody, but after the group was formed we started coming out of our houses, we started meeting other people and we feel nice about it (DPG member).

The increased confidence of people with disabilities was reported to have influenced local 
community perceptions of disability. An NGO staff member reported that after DPG formation, people with disabilities were now being called by their names rather than by their disability.

Before, people never called the children by their name, for example, if someone couldn't walk, they would call him a crippled man and if someone couldn't see, they would call him blind... So after the [DPG] started, the [NGO] who works over there started calling each child by their name [and now] the people in the surroundings are doing the same.

A number of the DPG members reported that the behaviour of people in society had changed since the DPGs formed.

\subsection{Support of local village leadership promoted DPG confidence}

It appeared that groups' confidence levels increased more rapidly when the village leader (Pradhan) provided the DPGs with a space in which to meet. "If a meeting is held in a government place, the confidence level is more among the DPG." (NGO staff member)

Formation of DPGs seemed to encourage local village leadership to increase their support of people with disabilities.

Before, the Pradhans didn't do any work for us or didn't show any interest in doing our work, but now since our group is made, the Pradhans work in our favour (DPG member).

Although all groups reported having a good relationship with the Pradhan since DPGs formed, there were reports from some DPG members that the Pradhan did not always effectively communicate knowledge about government schemes and entitlements for people with disabilities. When asked about their knowledge of such information, one DPG member reported that the Pradhan informed them about the schemes but that, "We [often] come to know later on when the scheme is already closed."

\subsection{Barriers in the built environment hinder participation in DPGs}

Barriers in the physical environment significantly limited the involvement of people with disabilities in DPGs and in broader society. Physical barriers existed in all contexts, but were especially evident in the mountain regions.

[Other NGO staff]... were shocked because of the geographical condition of this place. There are many ups and downs on the road... so it's very difficult. Our place is not suitable for disabled people-we don't have a ramp, and in hilly areas wheelchair won't go in all places even walking with crutches is difficult (NGO staff member).

A range of governmental, social, and economic factors limited the ability to make changes to the environment. When the physical environment was a barrier for people with disabilities, they seemed to rely on NGO or family support to enable their involvement in the group. "The [NGO] representatives of the group go to their house and tell what happens in the meeting so that they don't feel left out." (NGO staff member)

\section{Summary: Group composition}

It was found that DPGs had the capacity to create environments in which members of socially and culturally diverse backgrounds were able to meet as equals, united by disability. In most groups, however, people with profound disabilities were unable to regularly participate in group meetings and activities, and so were largely excluded from the relational benefits of DPGs.

\subsection{DPGs promoted equality among socially and culturally diverse members}

DPGs seemed to create environments in which disability was the unifying and equalising factor among individuals of socially and culturally diverse backgrounds. Members of several DPGs echoed that they experienced "no problem" forming a group with people of different cultures, religions, 
and castes. It seemed that relational cohesion among group members was both a mechanism that promoted group formation and function, and also an outcome of group formation that members perceived as valuable. When asked what the best thing about the DPG was, several members shared similar thoughts related to group unity. "Everybody gathers and... we get to meet each other. This is the good thing that I like" (DPG member). Another member reported, "The best part is unity."

\subsection{DPGs were not equally inclusive of people with profound disabilities}

Despite all DPGs reporting strong group unity, it was clear that not all people with disabilities benefitted equally from this unity and relational cohesion. People with profound disabilities - particularly those who were unable to easily leave their homes-were often unable to attend group meetings and functions, and thus unable to participate in the process of meeting as a unified group. "There are some disabled people in society who are not able to come to this group because there is no helper for them." (DPG member) When asked if DPGs had been beneficial to people with severe disabilities, one NGO staff member acknowledged, "I must say, not fully." In this project there was minimal participation from people with profound disabilities in FGDs, and when such individuals did participate, family members often spoke on their behalf.

\section{Discussion}

This study demonstrated that a range of different contextual factors influenced the formation of DPGs. External organisations, village leadership, and group champions played significant roles supporting the establishment of DPGs. DPGs displayed a capacity for increasing the confidence of group members and stimulating positive community changes in regard to disability, through altering societal understandings of disability and improving inclusion and participation of people with disabilities. Strong relationships within groups were of key importance, and DPGs seemed to function more effectively when they developed networking relationships with other similar groups.

One of the principles of realist evaluation is that findings are provisional and largely dependent on context. ${ }^{10-12}$ As this study was conducted in one area of India and looked at only one model of DPGs, the findings may not be applicable to other contexts. Nevertheless, a review of the literature and validation from experts involved in supporting formation of groups of people with disabilities in other contexts, reinforce many of the findings of this study, and suggest that despite limitations, there are still useful observations that may be applied to other contexts. $^{15-23}$

For example, in this study, the group champion helped to facilitate the formation of DPGs. In most cases, people with disabilities were initially reluctant to join the DPG, but reported changing their minds because of the consistent efforts of an NGO staff member who promoted the importance of disability inclusion within the NGO, invested in building trusting relationships with people with disabilities, and educated people with disabilities and their families about the potential benefits of forming DPGs. This finding is consistent with literature highlighting the role of network "brokers" in the formation of networks. $^{14,24,25}$ In the literature, network brokers are often organisations that play key facilitating roles in the development of networks. The network brokers in this context, however, were typically sole NGO staff members who undertook to engage DPG members, bring together people with disabilities from different backgrounds, create channels of effective communication, and collaborate with people with disabilities to establish operating rules (or models) for the DPGs.

Other published literature from different settings and contexts also echoes some of the findings of this evaluation, reinforcing the suggestion that the results of this study may be applicable to other contexts. For example, a study 
of DPOs in $\mathrm{Nepal}^{18}$ in suggested that DPO members were more confident and more connected with society after joining groups. This was similar to the observations made in this study that development of networks between DPOs improved individual and group identity, and confidence. Literature from other geographical and contextual settings also reinforced many of the findings of this study pertaining to the barriers faced by DPGs. Discriminatory societal views were reported to be barriers for groups in Bolivia ${ }^{19}$ and India, ${ }^{21}$ as was observed in this evaluation. Accessing DPGs in rural areas was also found to be a major barrier for DPOs operating in different rural settings in India, ${ }^{17}$ suggesting that this may be a common barrier in rural Indian settings generally, rather than in the mountain regions specifically.

It is important to study the relationship between groups of people with disabilities and external entities in order to understand how people with disabilities can be supported to achieve their rights on an equal basis with all others. Observations made in this study suggested that involvement of external entities in DPG formation could be empowering for people with disabilities when undertaken collaboratively. It was observed that involvement of external entities was often beneficial for DPG formation by way of providing awareness and education to people with disabilities and their communities about the rights of people with disabilities, and the potential of DPGs to realise these rights. Moreover, external entity financial and technical training support was beneficial to groups, promoting agency. Despite initial reliance on external support, all groups in this study went on to form leadership and governance structures of their own and became officially registered DPOs. This suggests that groups of people with disabilities can become user-led organisations, even after initially being externally resourced.

The Lancet's recent series "Faith-based health care" highlighted the important roles faith and faith-based structures play in influencing health and behaviours that impact health and development. ${ }^{26-27}$ Consistent with these articles, our research indicates that faith can impact responses to disability and that the values of faith-based organisations (FBOs) affect their response. ${ }^{26-27}$ Predominant social and cultural views of disability in the areas visited in this project historically centred on the view of disability as a "curse." Past models for engagement of people with disabilities in these areas, therefore, tended to be medical or charitable - with disability seen as an issue to be fixed or a condition deserving pity. ${ }^{13}$ Although many secular groups as well as a variety of religious organisations adopt rights-based approaches to disability, NGO staff in this study attributed their involvement in collaborative, rightsbased approaches to their Christian faith and their belief that people with disabilities were made in the "image of God". NGO staff reported that this view shaped the way that they developed partnerships with people with disabilities, and the way they delivered education and awareness about the rights of people with disabilities. There was some indication that these values had helped change societal attitudes toward disability with many respondents reporting that the view of disability as a curse was no longer so prevalent after DPGs were formed. This observation suggests that faith can contribute to responses to disability and reinforces the Lancet's finding that FBOs may affect healthrelated attitudes and behaviours of communities. ${ }^{26}$ While faith and FBOs appeared to play a positive role in this study, the Lancet's series highlights that this is not always the case - in some cases, religious beliefs may be counter to a human rights framework. ${ }^{27}$ This is an area that requires further study to be better understood. Regardless of the role of faith, the Lancet's call for greater collaboration with FBOs ought to be considered. ${ }^{26}$

Groups of people with disabilities are designed to be inclusive groups that promote the rights and participation of marginalised persons (people with disabilities). Observations in this study suggest that such groups may not fulfil this goal equitably. For example, we observed that 
individuals with profound disabilities were less involved in DPGs than people with less significant functional impairments. The literature indicates that these populations, particularly individuals with intellectual or psychosocial disabilities, are the most marginalised of all people with disabilities, and thus invite further reflection on their participation in DPGs. ${ }^{28,29}$ Several factors in this study, including logistical, environmental and attitudinal barriers, disempowerment, lack of prioritisation of people with profound disabilities in the process of DPG formation, or even perceived lack of benefit from participating in groups may have contributed to the observed low participation of these populations in DPGs. These factors need to be considered in future, and it would be advantageous for organisations involved in disability-inclusion work to advocate for and promote the agency of such individuals and their participation in DPGs and broader society.

\section{Limitations}

This study was conducted by researchers who did not have disabilities, a factor that may have affected the quality of the data obtained. An emancipatory approach-,i.e., training people with disabilities to serve as co-researchers-would likely be a better model in future studies. In this study, NGO staff assisted the researchers to recruit participants for FGDs and, as such, may have introduced bias into the sampling of individuals with a tendency for inclusion of DPG members who had positive experiences of DPGs and who were more confident or able to communicate with researchers (i.e., there may have been a tendency to exclude people with profound disabilities or communication difficulties). On the whole, responses from DPG members were favourable toward the NGO and the DPG with very few critical reports from participants. FMs were often present during FGDs, which may have limited the extent to which DPG members felt comfortable answering questions openly. FGDs by nature also may not promote equal contributions from all participants.
In this study, despite training local research assistants in facilitating FGDs, it was not always possible for the authors to ensure that discussions encouraged all participants to contribute their views. Due to limited time, financial and personnel resources, there were limited opportunities for equal inclusion of people with communication difficulties. With more ample resources, the study could have recruited co-researchers with expertise in communicating with such populations. Due to the limitations of this study, the authors did not feel they gained sufficient data from the perspective of these individuals with profound disabilities or communication difficulties to ascertain whether they had received any personal benefit from the DPGs.

\section{Further research}

This study begins to provide some insights into the influence of contextual factors on the formation and function of groups of people with disabilities. Further research of groups in other contexts would provide contrast to suggest whether the present findings apply elsewhere. Longer-term follow up of DPGs that have received external support for their formation would assist with understanding what the long-term effect of external supports are on such groups. Studies of DPGs that have become DPOs would also be beneficial for understanding the process of empowerment and the transition of groups from external to internal resourcing. Finally, investigation of the role of different religious beliefs in shaping a response to disability could provide useful insights for faithbased organisations seeking to be involved in disability-inclusion work. A cluster-randomised trial of DPGs is currently being undertaken in Northern India and may provide data on all of these areas of interest.

\section{Conclusion}

Disability-inclusive development strategies in LMICs often involve the formation of groups of people with disabilities. Although there is evidence 
that DPGs can achieve beneficial outcomes for people with disabilities, little is understood about how contextual factors affect their formation and function. This study demonstrated that external organisations could play an important facilitating role in the formation of DPGs, especially when this was undertaken in collaboration with people with disabilities. Support from local village leadership was important for group formation, but the benefit of this support was amplified when DPGs formed strong networks with other, similar groups. The existence of DPGs could stimulate positive societal changes in regard to disability through altering societal understandings of disability, and improving inclusion and participation of people with disabilities.

\section{References}

1. UN: Final report of the ad hoc committee on a comprehensive and integral international convention on the protection and promotion of the rights and dignity of persons with disabilities [Internet]. United Nations; c2007 [updated 2006 December 6; cited 2016 June 9] Available from: http://www.un.org/esa/socdev/enable/rights/ahcfinal repe.htm

2. WHO: World report on disability [Internet]. World Health Organisation; c2011 [cited 2016 June 9] Available from: http://www.who.int/disabilities/world_report/2011/r eport.pdf

3. WHO: Health statistics and information systems [Internet]. World Health Organisation; c2016 [cited 2016 April 7] Available from: http://www.who.int/healthinfo/global_burden_disea se/definition_regions/en/

4. Kumar S, Roy G, Kar S. Disability and rehabilitation services in India: issues and challenges. J Family Med Prim Care. 2012; 1(1): 69-73. http://dx.doi.org/10.4103/2249-4863.94458

5. Ramachandra S, Allagh K, Kumar H, Marella M, Pant H, Mahesh, D et al. Prevalence of disability among adults using rapid assessment of disability tool in a rural district of South India. Disabil Health J. [Forthcoming 2016].
6. Disabled people's organisation (DPOs) [Internet]. People with Disabilities Australia. c2010-2016 [cited 2015 September 16] Available from: http://www.pwd.org.au/student-section/disabledpeople-s-organisations-dpos.html

7. Enns $\mathrm{H}$. The role of organizations of disabled people: a disabled peoples' international discussion paper [Internet]. Independent Living Institute; 2015. Available from:

http://www.independentliving.org/docs5/RoleofOrg DisPeople.html

8. CBM: Inclusion made easy: a quick program guide to disability in development [Internet]. CBM; [updated May 2012 May 29; cited 2016 May 10]. Available from: http://www.cbm.org/article/downloads/78851/CBM _Inclusion_Made_Easy__complete_guide.pdf.

9. Young R, Reeve M, Grills N. The function of disabled peoples' organisations (DPOs) in low- and middle-income countries: a literature review. DCID Journal. [Forthcoming 2016].

10. Realist evaluation. Better evaluation [Internet]. 2014. [cited 2015 September] Available from: http://betterevaluation.org/approach/realist_evaluati on

11. Overseas Development Institute. Realist impact evaluation: an introduction [Internet]. ODI, Westhorp [updated 2014 September; cited 2016 September 9] Available from: http://www.odi.org/publications/8716-methods-labrealist-impact-evaluation-introduction

12. Pawson R, Tilley N. Realistic evaluation. London: Sage Publications; 1997.

13. McNair J. Disability and human supports. Christ J Glob Heal. 2015; 2(2):10-5. http://dx.doi.org/10.15566/cjgh.v2i2.86

14. Grills N, Robinson P, Phillip, M. Networking between community health programmes: a case study outlining the effectiveness, barriers and enablers. BMC Health Serv Res. 2012; 12(206). http://dx.doi.org/10.1186/1472-6963-12-206

15. Armstrong M. Disability self-help organizations in the developing world: A case study from Malaysia. Int J Rehab Res. 1993;16(3):185-94. http://dx.doi.org/10.1097/00004356-199309000$\underline{00002}$

16. Cobley D. Towards economic participation: examining the impact of the convention on the rights of persons with disabilities in India. Disabil 
Soc. 2013;28 (4):441-55.

http://dx.doi.org/10.1080/09687599.2012.717877

17. Deepak S, dos Santos L, Griffo G, de Santana D,

Kumar J, Bapu S. Organisations of persons with disabilities and community-based rehabilitation.

Asia Pac Disabil Rehabil J. 2013;24(3):5-20. http://dx.doi.org/10.5463/dcid.v24i3.269

18. Dhungana, Kusakabe K. The role of self-help groups in empowering disabled women: A case study in Kathmandu Valley, Nepal. Development in Practice. 2012;20 (7): 855-65. http://dx.doi.org/10.1080/09614524.2010.508244

19. Griffiths M, Mannan H, MacLachlan M. Empowerment, advocacy and national development policy: a case study of disabled peoples' organizations in Bolivia. In: Disability and international development: towards inclusive global health. New York: Springer US; 2009.

20. Kleintjes S, Lund C, Swartz L. Organising for selfadvocacy in mental health: experiences from seven African countries. Afri J Psychiat. 2013;16(3):18795. http://dx.doi.org/10.4314/ajpsy.v16i3.25

21. Kumaran K. Role of self-help groups in promoting inclusion and rights of persons with disabilities. Asia Pac Disabil Rehabil J. 2011; 22 (2): 105-13. http://dx.doi.org/10.5463/DCID.v22i2.78

22. Polu W, Mong A, Nelson C. Social and economic inclusion of people with disabilities: practical lessons from Bangladesh. Development in Practice. 2015; 25 (8). doi: 1182-1188. http://dx.doi.org/10.1080/09614524.2015.1078289

23. Stewart R, Bhagwanjee A. Promoting group empowerment and self-reliance through participatory research: a case study of people with physical disability. Disabil Rehabil. 1999;21(7): 338-45. http://dx.doi.org/ $\underline{10.1080 / 096382899297585}$
24. Grills N. The importance of networks in public health practice [dissertation]. Melbourne: Monash University; 2013.

25. Agranoff R. Collaborative public management: new strategies for local governments. Washington D.C.: Georgetown University Press; 2003.

26. Duff J, Buckingham W. Strengthening of partnerships between the public sector and faithbased groups. The Lancet. 2015;386(10005):178694. http://dx.doi.org/10.1016/S01406736(15)60250-1

27. Karam A, Clague J, Marshall K, Olivier J. The view from above: faith and health. The Lancet.

2015;386(100005). http://dx.doi.org/10.1016/S0140-6736(15)61036-4

28. Cornielje $\mathrm{H}$. The role and position of disabled people's organisations in community based rehabilitation: balancing between dividing lines. Asia Pac Disabil Rehabil J. 2009;20(1): 3-14. http://dx.doi.org/10.5463/dcid.v24i3.269

29. UN: Best practices for including persons with disabilities in all aspects of development efforts [Internet]. United Nations; c2011 [cited 2016 June 9] Available from:

http://www.un.org/disabilities/documents/best_prac tices_publication_2011.pdf

30. Census of India: district census handbook Dehradun [Internet]. Census of India; [cited 2016 June 9] Available from: http://www.censusindia.gov.in/2011census/dchb/05 05_PART_B DCHB DEHRADUN.pdf

31. Census of India: district census handbook Tehri Gahrwal [Internet]. Census of India; [cited 2016 June 9] Available from: http://www.censusindia.gov.in/2011census/dchb/05 04_PART_B_DCHB_TEHRI\%20GARHWAL.pdf

\section{Appendix 1: Primary CMO hypotheses}

\begin{tabular}{|c|c|}
\hline Theme & Hypotheses \\
\hline Involvement of an external entity & $\begin{array}{l}\text { Hypothesis 1: Affiliation of a DPG with a community-based rehabilitation (CBR) program will } \\
\text { lead to modelling of good organisational structures and practices, as well as providing support } \\
\text { and training for DPG members to develop the skills needed to initiate and sustain an } \\
\text { effectively functioning DPG (i.e. one that meets regularly, has stable governance structures and } \\
\text { has the means to access funding and action-group ideas) provided the DPG is peer-led from the } \\
\text { start. Affiliation between a DPG and CBR program, however, may lead to disempowerment of } \\
\text { DPG members, dependence on CBR staff external to the DPG, and lack of ownership on } \\
\text { behalf of members. }\end{array}$ \\
\hline
\end{tabular}


The role of key contributors

Composition of the group
Hypothesis 2: When family and community members, including the village Pradhan, ASHA* and Anganwadi worker*, support DPGs, groups are more likely to function effectively and achieve positive outcomes for members because of support in attending group meetings, stable and committed group membership, improved access to resources (including things like venues), and empowerment to have a 'voice' in the community (because of access to time with the Pradhan and other community leaders).

Hypothesis 3: If the village Pradhan is not supportive of DPGs, persons with disability (and thus also DPGs) will face continued discrimination and barriers to functioning (environmental, institutional and attitudinal). If the group is supported by other non-disabled persons or organisations who act as 'champions' for the group, encouraging participation of people with disabilities and activity of the DPG, the group is likely to develop a strong vision and resolve to advocate for their rights as stipulated in the Convention on the Rights of People with Disabilities. In the absence of external support and encouragement, groups (even those with strong internal leadership) are likely to experience disempowerment and discouragement, lack of incentive or difficulty in meeting regularly and a lack of group outputs.

Hypothesis 1: Groups who have a charismatic leader will develop stable membership and gain the support of village leadership, family members and external organisations as well as obtaining stable financial support because of their ability to communicate a strong vision, become visible in the public sphere and advocate for the rights of persons with disability. Groups that are led by a team of members rather than a single individual will produce greater outputs and improved outcomes for members due to leadership stability and sustainability (less burnout because of burden sharing), information sharing and pooling of skills in the leadership team, increased buy-in and involvement from group members and an increased number of member voices being heard during group meetings. When a single charismatic and strong leader runs the group, there is susceptibility for disempowerment of other members, poor representation of group opinions, burdening of the leader and group burnout in the long run although in the initial phases, groups are likely to have high outputs and gander external support as well as high membership numbers.

Hypothesis 1: Single disability groups are likely to experience greater levels of group unity and member involvement and participation than multi-disability groups meaning that groups can work more cohesively to develop and action goals and achieve outcomes for members. Group activities are likely to be more targeted to members' needs when groups are homogenous. Groups with heterogenous membership are likely to represent the needs of a wider group of individuals, but may result in the voices of some individuals being marginalised (e.g. women, elderly, children) and the views and agendas of more vocal group members being privileged. Groups that include parents or carers of people with disabilities assist the voices of severely impaired people with disabilities in being heard.

*Note: ASHA and Anganwadi workers are community-health workers

\section{Appendix 2: District demographic details}

\begin{tabular}{llllllcc}
\hline District & $\begin{array}{l}\text { Population } \\
\text { (total, urban) }\end{array}$ & $\begin{array}{l}\text { Area } \\
\left(\mathrm{km}^{2}\right)\end{array}$ & $\begin{array}{l}\text { Population } \\
\text { density } \\
\left(\text { person } / \mathrm{km}^{2}\right)\end{array}$ & $\begin{array}{l}\text { Literacy } \\
\text { (total, } \\
\text { female) } *\end{array}$ & Unemployment & Sex ratio ** SC, ST \\
$* * *$
\end{tabular}

*State average literacy: $78.82 \%$

**Sex ratio is the number of females per 1000 males, state average is 963 females per 1000 males

***Scheduled caste (SC) and scheduled tribe (ST) 


\section{Appendix 3: Interview guides}

*N.b. in these interviews, the term DPO was used to refer to groups as this is typically the name that group members used to refer to their groups

\section{Focus Group Discussion Schedule: DPG members}

Demographics (to be asked of individuals before commencement of the FGD)

1. What is your gender?

2. What is your age?

3. Tell me about the kind of disability(ies) you have (be specific)?

4. What is your religion?

5. What is your caste?

6. Do you work? If so, what do you do for work?

7. How many times have you met with the DPO*?

\section{Question Guide}

1. Tell me the story about how the DPO started and describe how the DPO was formed. Prompt:

- Member selection (what about people with disabilities in the community who do not attend the group?)

- Reason for starting the group

- Who else was involved in starting the group (e.g., NGO, hospital, etc.) and what were their roles?

2. What was life like before the DPO started? Has the DPO had any impact on your life now? If so, how? Prompt:

- $\quad$ Overall life satisfaction and well being (Prompt: Does being in the group make you feel more confident?)

- Education

- Employment and/or income generation

- Attitudes in the community toward you and other people with disabilities

- Friendships and social interaction (Have you had the chance to make more friends through your involvement in the group?)

- Access to people in positions of authority (e.g., the Pradhan, government, doctors, etc.) and participation in community consultation)

- Knowledge of your rights (Do you know more about your rights now?)

- Access to Government social welfare? (Are you able to access the things you know about now?)

- Ability and opportunity to help others (Do you think you have things you can offer to other group members or other members of society?)

3. What activities has the DPO been involved in, if any? Prompt:

- Advocacy

- Fundraising

- Environmental modifications (e.g., home modifications, improving environmental accessibility in the village, etc.)

- Community awareness raising

- Training

4. Do you think the DPO is functioning well? If yes, what makes you think it is functioning well?

5. In what ways do you think the group could be functioning better? Prompt:

- Weakness of the group

- Difficulties that the group has faced

- Areas for improvement

- Disappointments people have in the group

6. Tell me about the following things and how each of them impacts the group.

- The relationship of the DPO with the NGO (How involved is the NGO? Has this been helpful? Is there any way that this has been unhelpful?)

- The leadership of the DPO (What is the leadership structure and how is it working?)

- The location of the DPO (Is the location easy to access? Or are there many who would like to be part of the group who cannot be because it is difficult to access?) 
- The money or assets that the DPO has access to (What money does the group have? Has the group applied for or been able to access grants or funds from the government or other organizations? Does money greatly affect what the group can and can't do?)

- The group composition (types of disability represented, involvement of parents or care-givers, caste or religion, etc.)

- Networks with other DPOs or similar groups

7. Do you think that the group can have or has been advantageous for other people in society? (e.g., elderly, women, children)

8. Do you think you will continue to meet as a DPO?

9. What, in your opinion, is the best thing about this group?

\section{Semi-structured interview: FM}

\section{Demographic questions}

1. When was the DPO formed and when did it first meet?

2. How many times has the DPO met since it was formed?

3. Does the DPO have a constitution? And when was it formed?

4. Is the DPO registered? When was it registered?

5. How many people are in the DPO? (Prompt about total number of members, number of male/ female, number that regularly attend meetings, age, type of disability, education, employment, etc.)

6. Does the DPO have any money or assets and if so, who/where do these come from? Has the DPO been able to access funding aside from that provided by the NGO?

\section{Question Guide}

1. Tell me the story of how the DPO formed. (Probe about whether the DPO faced any particular difficulties in its formation.)

2. Has the DPO had any positive impact for its members since forming? (Probe about the types of positive impacts and what the difference is from before the DPO formed till now.)

- Societal attitudes (e.g., Do people in the community see people with disabilities differently since the group started?)

- Access to resources including government schemes and funding (and do you think access to these is likely to change once the group is registered?)

- Knowledge about rights

- Overall life satisfaction and well being

-Education

-Employment and/or income generation

- Friendships or social interactions

- Access to people in positions of authority (e.g., the Pradhan, government, doctors, etc)

- Participation in community life and community consultation

3. Has the DPO had any impact on broader society since forming? And if so, what sort of impact? (prompt: gender and caste equality outside of group)

4. Do you think the DPO is functioning well? What makes you think it is functioning well?/What things would make you say it was functioning well?

5. How did the following factors impact upon the functioning of the DPO if at all? (ask only if not already covered above) Prompt:

- The relationship of the DPO with the NGO (prompt: Do you think the group would keep meeting if the NGO stopped being involved?)

- The leadership of the DPO (prompt: Does the group have a leadership committee? How and why were they elected?)

- The location of the DPO and its members

- The money or assets that the DPO has access to

- The caste/gender/religion of individual members

- Networks with other DPOs or similar groups

6. What do you hope to gain from your involvement in this DPO? Is it achieving what you want?

7. Do you have any suggestions for how the DPO could become better and more effective? (e.g. Do you think they should continue to meet and if so how and why?)

\section{Follow-up written questions}

Nov 2016. Christian Journal for Global Health, 3(2): 72-90. 
1. Do you have a personal faith? If so, please tell me about your faith.

2. Does your faith influence the way you view people with disabilities? And if so, how?

3. Has your faith had any impact on the way your organisation has gone about forming DPOs? If so, how?

\section{Semi-structured interview: Key informant}

\section{Question Guide}

1. How have you been involved with the DPO since it was formed? (Prompt: Why are you involved?)

2. Have you had more contact with people with disabilities since the DPOs were formed? In what ways?

3. Has the DPO had any positive impact for its members since forming? What was life like for people with disabilities before the group was formed? Prompt:

- Societal attitudes

- Access to resources including government schemes and funding

- Knowledge about rights

- Overall life satisfaction and well being

- Education

- Employment and/or income generation

- Friendships or social interactions

- Access to people in positions of authority (e.g., the Pradhan, government, doctors, etc.)

- Participation in community life and community consultation

4. Has the DPO had any impact on broader society since forming? And if so, what sort of impact?

5. Do you think the DPO is functioning well? What makes you think it is functioning well?/What things would make you say it was functioning well?

6. What are some of the difficulties that this group faces? Prompt:

- Finances

- Environmental barriers

- Diversity in group membership

7. Do you know of many people with disabilities in the community who are not part of this group? Why are they not?

8. How did the following factors impact upon the functioning of the DPO if at all? (ask only if not already covered above) Prompt:

- The relationship of the DPO with the NGO

- The leadership of the DPO

- The location of the DPO and its members

- The money or assets that the DPO has access to

- Networks with other DPOs or similar groups

9. What do you hope can be achieved by having DPOs in your community?

10. What is the best thing about this group?

11. Do you have any suggestions for how the DPO could become better and more effective?

Peer Reviewed

Competing Interests: None declared.

Acknowledgments: This work was supported by a grant from CBM India. Thank you to Nicole Butcher for her assistance in editing this manuscript.

Correspondence: Rebekah Young, University of Melbourne, rryoung1991@gmail.com

Cite this article as: Young R, Reeve M, Devine A, Singh L, Grills N. A realist evaluation of the formation of groups of people with disabilities in North India. Christian Journal for Global Health (Nov 2016), 3(2):_.

(C) Young R, Reeve M, Devine A, Singh L, Grills N. This is an open-access article distributed under the terms of the Creative Commons Attribution License, which permits unrestricted use, distribution, and reproduction in any medium, provided the original author and source are properly cited. To view a copy of the license, visit http://creativecommons.org/licenses/by/4.0/

www.cjgh.org

Nov 2016. Christian Journal for Global Health, 3(2): 72-90. 